\title{
VALIDITAS MODUL BERBASIS KEARIFAN LOKAL KABUPATEN TUBAN BAGI SISWA KELAS IV SEKOLAH DASAR
}

\author{
Arik Umi Pujiastuti \\ arik.umi86@gmail.com \\ Pendidikan Guru Sekolah Dasar, Fakultas Keguruan dan Ilmu \\ Pendidikan, Universitas PGRI Ronggalawe
}

\begin{abstract}
Abstrak: Modul adalah salah satu bahan ajar yang dapat digunakan siswa belajar secara mandiri. Adanya pembelajaran tematik yang dilakukan di SD menjadikan pembelajaran terfokus pada tema-tema yang dekat dengan kehidupan siswa atau kontekstual. Salah satu tema yang dipelajari adalah daerah tempat tinggalku. Pada tema tersebut selama ini belum didapatkan bahan ajar yang sesuai dengan kearifan lokal Tuban. Masalah tersebut menjadikan peneliti memberikan alternatif pemecahan dengan mengembangkan modul berbasis kearifan lokal Kabupaten Tuban. Tujuan dari penelitian ini adalah mendeskripsikan validitas dari modul yang dikembangkan yaitu, modul berbasis kearifan lokal. Validitas modul dilihat dari tingkat kelayakan modul berdasarkan validasi yang dilakukan oleh ahli desain, ahli materi, dan ahli bahasa dengan demikian instrumen yang digunakan adalah lembar validasi. Tingkat kelayakan ditunjukkan melalui hasil persentase dari penilaian validator ahli desain, ahli materi dan ahli bahasa. Berdasarkan hasil validasi desain persentase sebesar 92\% dengan kriteria sangat layak, dari hasil penilaian ahli materi sebesar $75 \%$ dengan kriteria layak, dan penilaian ahli bahasa sebesar $85 \%$ dengan kriteria sangat layak. Hasil validasi dari ketiga ahli tersebut menunjukkan hasil persentase tingkat kelayaan modul sebesar $84 \%$ dengan kriteria sangat layak.
\end{abstract}

Kata kunci: validitas modul, berbasis kearifan lokal kabupaten Tuban.

\section{THE MODULE VALIDITY BASED ON LOCAL WISDOM TUBAN DISTRICT FOR GRADE IV ELEMENTARY SCHOOL STUDENT}

\begin{abstract}
The module is one of the lessons students can use on their own. Having thematic learning done in sd makes learning focused on subjects that are close to student or contextual life. One of the themes was where I lived. The theme has not yet been obtained with local wisdom from tuban. The problem made researchers an alternative breakthrough by developing the local magic-based module of tuban district. The purpose of research is to describe the validity of the developed module, which is a local prudence based module. Validity of the module is viewed at the worthiness level of
\end{abstract}


Arik. Validitas Modul Berbasis Kearifan...

the module based on validation performed by design experts, materials experts, and linguists, thus the instrument used is a validation sheet. The measure of worthiness is demonstrated by the percentage of the validator assessment of design experts, materials experts and linguists. Based on the results of $92 \% \%$ designs with the highest criteria, from a materials assessment of $75 \%$ with viable criteria, and a linguist assessment of $85 \%$ with the most viable criteria. Validation results from all three experts indicate an $84 \%$ increase in the module's adjust-level efficiency with very reasonable criteria.

Keywords: validity of the module, based on local prudence of the tuban district.

\section{PENDAHULUAN}

Kabupaten Tuban adalah salah satu kabupaten yang berada di Propinsi Jawa Timur. Tuban sendiri memiliki potensi yang luar biasa baik dari sektor pertanian, perkebunan, laut, tambang, industri bahkan wisata. Potensi tersebut sangat memungkinkan untuk dimanfaatkan menjadi sumber belajar yang dikembangkan dalam bahan ajar bagi siswa di Sekolah Dasar. Bahan ajar sendiri memiliki peranan penting dalam kegiatan pembelajaran, karena hal tersebut guru harus memiliki inovasi dalam mengembangkan bahan ajar yang disesuaikan dengan tujuan pembelajaran (Lamahala, Lamen, Uslan, 2018). Pada pengembangan bahan ajar menurut (Anwar, Ruminiati, Suharjo, 2017) secara substansi harus mencerminkan pembelajaran yang kontekstual atau berbasis kearifan lokal bagi siswa Sekolah Dasar.

Sebagai salah satu jenjang pendidikan, Sekolah Dasar sendiri merupakan pendidikan formal tingkat dasar dengan tujuan membentuk pondasi sikap, keterampilan dan pengetahuan (Alba, Akbar, Nurchasanah, 2019). Sehingga kompetensi yang dimiliki siswa Sekolah Dasar akan berpengaruh pada kompetensi pada jenjang pendidikan selanjutnya (Deviana, 2018). Berdasarkan kurikulum 2013 pembelajaran di Sekolah Dasar menggunakan tema dengan pendekatan saintifik sehingga, kegiatan pembelajaran dan substansi bahan ajar harus kontekstual dan berbasis kearifan lokal lingkungan sekitar (Anwar, Ruminiati, Suharjo, 2017). Adanya bahan ajar berbasis kearifan lokal dapat memberikan pengalaman belajar yang bermakna bagi siswa sehingga tujuan pembelajaran dapat tercapai sesuai dengan tujuan yang dirumuskan (Laksana, Kurniawan, Niftalia, 2016).

Hasil wawancara dengan guru kelas IV Sekolah Dasar, bahan ajar yang selama ini digunakan pada tema tempat tinggalku hanya menggunakan buku siswa dan hal tersebut 
Arik. Validitas Modul Berbasis Kearifan...

menyulitkan siswa dalam memahami tema dan secara tidak langsung berpengaruh terhadap pengalaman belajar siswa. Masalah lain muncul saat terjadinya pandemi Covid 19 di mana pembelajaran harus dilakukan secara mandiri di rumah dengan pendampingan orang tua. Banyaknya keluhan dari orang tua terkait sulitnya menjelaskan tema tersebut kepada anaknya menjadikan peneliti memberikan alternatif pemecahan masalah dengan pengembangan modul berbasis kearifan lokal. Modul sendiri merupakan salah satu bahan ajar yang dapat membantu siswa belajar secara mandiri (Chusna, Ekowati, Kuncahyono, 2019), (Oktaviana, Hartini, Misbah, 2017) mengartikan modul sebagai salah satu bahan ajar cetak yang berisi materi pembelajaran dan evaluasi, baik tes ataupun nontes serta memuat tujuan pembelajaran dan disusun dengan tujuan membantu siswa belajar secara mandiri, penelitian yang dilakukan (Irfan, 2014) menerangkan bahwa Modul bahan ajar yang di mana pengorganisasian materi pelajaran disesain untuk siswa agar bisa belajar secara mandiri. penelitian sebelumnya yag dilakukan Rozhana dan Anwar (2019) modul merupakan salah satu bahan ajar yang disusun berdasarkan karakteristik dan kebutuhan siswa yang disesuaikan dengan lingkungan siswa. Penelitian terdahulu yang dilakukan Saputra, Wahyuni, \& Handayani (2016) mendeskripsikan bahwa modul adalah salah satu bahan ajar yang dirancang untung membantu siswa belajar dengan ataupun tanpa bimbingan guru. Adanya pengembangan modul yang dilakukan maka sebelum modul digunakan perlu diuji validitas tingkat kelayakan kepada validator ahli. Sehingga penelitian yang dilakukan bertujuan mendeskripsikan bagaimana validitas tingkat kelayakan modul berbasis kearifan lokal Kabupaten Tuban bagi kelas IV Sekolah Dasar.

\section{Modul Pembelajaran}

Modul adalah bahan ajar yang di desain guna membantu siswa menyelesaikan tujuan-tujuan pembelajaran tertentu, selain itu modul merupakan bahan ajar yang dapat digunakan oleh siswa untuk belajar secara mandiri dengan bantuan seminimal mungkin dari orang lain Munadi (2010). Menurut Daryanto (2013) modul merupakan salah satu pendamping bahan ajar yang dikemas secara utuh dan memiliki desain yang menarik untuk membantu siswa memahami secara cepat dan menguasai tujuan pembelajaran dengan baik. berdasarkan penelitian sebelumnya oleh Rahdiyanta, (2016) menjelaskan modul merupakan bentuk dari bahan ajar yang dikemas secara rinci dan utuh secara sistematis, didalamnya memuat pembelajaran yang terencana dan didesain untuk 
Arik. Validitas Modul Berbasis Kearifan...

membantu siswa dalam mencapai tujuan pembelajaran. dalam hal ini modul bida disefinisikan sebagai salah satu bahan ajar di mana secara konten materi dapat membantu siswa dalam kegiatan pembelajaran baik dengan atau tanpa bimbingan dari guru.

Menurut penelitian yang dilakukan Irfan, (2014), menjelaskan beberapa karakteristik dari modul yaitu, 1) self instructional (Pembelajaran Mandiri), Siswa mampu belajar secara mandiri tanpa ketergantungan dengan orang lain, 2) self Contained (Mandiri), Seluruh materi pembelajaran dari satu unit kompetensi yang dipelajari terdapat didalam satu modul utuh, 3) stand Alone (Berdiri Sendiri), Modul yang dikembangkan tidak harus digunakan bersama-sama media yang lain, 4) adaptif (Adaptasi), Modul hendaknya memiliki daya adaptif yang tinggi terhadap perkembangan ilmu dan teknologi, 5) user friendly (Mudah Digunakan), Modul hendaknya juga memenuhi kaidah akrab bersahabat/akrab dengan pemakainya, 6) konsistensi, Konsisten dalam penggunaan font, spasi, dan tata letak. Selain itu karakteristik lainnya adalah, 1) modul dirancang untuk sistem pembelajaran mandiri, 2) berisi program pembelajaran yang utuh dan sistematis, 3) berisi tujuan, bahan/kegiatan dan evaluasi pembelajaran, 4) disajikan dengan bahasa yang komunikatif, berupaya agar dapat mengganti beberapa peran pengajar.

\section{Kearifan Lokal}

Kearifan lokal merupakan hal yang menyatu dengan kehidupan sekelompok masyarakat di suatu daerah tertentu berasal dari warisan yang sudah turun temurun di mana berisi tentang sekelompok nilai-nilai kehidupan yang dianut oleh masyarakat tertentu (Tinja, Towaf, \& Hariyono, 2017). Menurut penelitian Alus (2014) kearifan lokal sendiri merupakana gagasan yang bersifat bijaksana, penuh kearifan, berbudi luhur yang dimiliki oleh masyarakat. Fajarini (2014) dalam penelitiannya menyebutkan bahwa kearifan lokal merupakan pendangan hidup dan ilmu pengetahuan serta berbagai strategi kehidupan yang berwujud aktivitas yang dilakukan oleh masyarakat lokal dalam menjawab berbagai masalah dalam pemenuhan kebutuhan hidup mereka. Selanjutnya Musanna (2012) menjelaskan bahwa kearifan lokal mengandung nilai-nilai potensial yang diperlukan untuk mewujudkan pendidikan yang lebih bermakana dan relevan dengan situasi sosial dan budaya. Penelitian lain dilakukan Anwar, Ruminiati, \& Suharjo (2017) bahwa kearifan lokal merupakan warisan dari para pendahulu disuatu 
Arik. Validitas Modul Berbasis Kearifan...

daerah yang dapat dilihat dari nilai agama, adat-istiadat, dan budaya yang selalu dipegang teguh oleh sekelompok masyarakat di daerah tertentu, selain itu kearifan lokal merupakan konsep tentang nilai-nilai luhur yang diwariskan nenek moyang yang digunakan sebagai pedoman kehidupan pada sekelompok masyarakat tertentu (Rukiyati \& Purwastuti, 2016). Penelitian terdahulu menyebutkan bahwa kearifan lokal merupakan warisan yang dipertahankan sebagai identitas dan pedoman oleh suatu masyarakat di mana berisi tentang kepercayaan, adat istiadat, nilai, norma, dan pengetahuan (Utari, Degeng, \& Akbar, 2016). Dengan demikian menurut (Wafigni \& Nurani, 2018) kearifan lokal dapat dimaknai sebagai ciri khas yang berisi nilai-nilai budaya, ekonomi, serta dipegang teguh oleh masyarakat tertentu dan mendapat pengakuan masyarakat lain.

Berdasarkan uraian pada pendahuluan maka tujuan penelitian ini adalah, mengetahui validitas modul berbasis kearifan lokal dari Kabupaten Tuban. Validitas pada modul ini berdasarkan penilaian dari ahli desain, ahli bahasa, dan ahli materi.

\section{METODE}

Metode yang digunakan adalah, penelitian dan pengembangan, di mana Sugiono (2015:407) menjelaskan bahwa penelitian pengembangan adalah metode penelitian yang digunakan untuk menghasilkan produk tertentu. Prosedur menggunakan 4-D terdiri dari 4 tahap yaitu, pendefinisian (define), tahap perancangan (design), tahap pengembangan (develop), dan tahap penyebaran (disseminate) dan disajikan pada gambar 1 berikut: 
Arik. Validitas Modul Berbasis Kearifan...

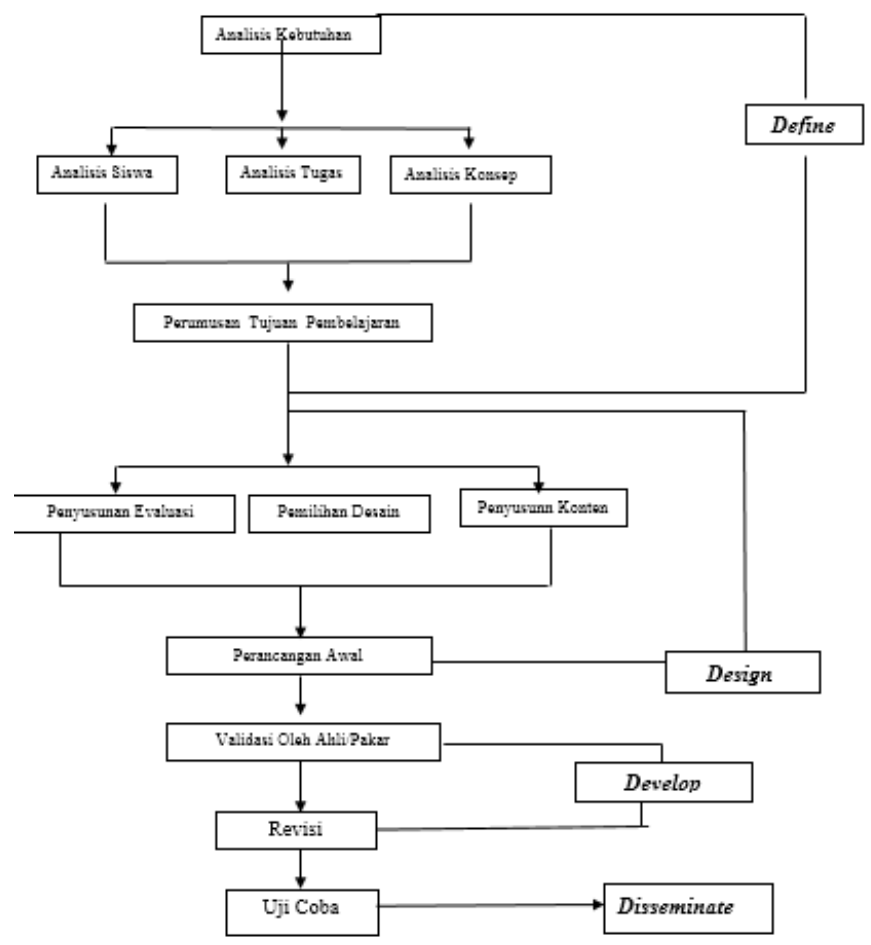

Gambar 1. Prosedur Penelitian Pengembangan (Trianto, 2011)

Deskripsi dari gambar 1 adalah sebagai berikut.

1. Tahap Pendefinisian (Define)

Pada tahap ini data awal dikumpulkan. Tahap ini meliputi analisis kebutuhan, analisis siswa, analisis tugas, analisis konsep, perumusuan tujuan pembelajaran. Analisis ini bertujuan menentukan masalah dasar yang akan di angkat dalam pengembangan modul berbasis kearifan lokal Kabupaten Tuban. Pada pelaksanaan analisis ini di lakukan pada buku ajar yang digunakan kelas IV SD. Pada analisis kebutuhan tim peneliti menganalisis kebutuhan dari siswa dimana hal tersebut terkait kebutuhan bahan ajar pendamping saat kegiatan pembelajaran secara blended learning.Analisis siswa bertujuan mengetahui karakteristik siswa yang akan di jadikan uji coba pengembangan modul yang meliputi tahap perkembangan berpikir, sikap dan keterampilan yang dimiliki. Analisis tugas adalah, merumuskan tugas yang disajikan pada modul. Analisis konsep merupakan kegiatan mengidentifikasi dan menganalisis konsep-konsep yang berorientasi kearifan lokal Kabupaten Tuban yang akan disajikan dalam modul. Konsep tersebut di disesuaikan dengan rumusan 
Arik. Validitas Modul Berbasis Kearifan...

indikator pembelajaran dan pada perumusan tujuan Pembelajaran adalah, merumuskan tujuan pembelajaran yang akan di capai setiap pembelajarannya.

2. Tahap Perancangan (design)

Berdasarkan hasil pendefinisian (define) pada tahap ini yang dilakukan adalah, penyususnan evaluasi, penyususnan konten, pemilihan desain, dan perancangan awal. Pada penyusunan evaluasi menggunakan dua jenis yaitu, tes dan non tes. Pada tes berupa pilihan ganda dan non tes adalah evaluasi keterampilan yang terdiri dari, ayo mengamati, ayo mencoba, ayo berlatih, ayo membaca, ayo berdiskusi, dan ayo bernyanyi. Penyususnan Konten menentukan apa yang menjadi dasar dan bahan untuk menyusun modul berbasis kearifan lokal Kabupaten Tuban yang mana di dalamnya terdiri dari halaman, pembelajaran 1 sampai 6 tema daerah tempat tinggalku subtema 1. Pada pembelajaran tematik ini memuat materi yang terdiri dari PPKn. SBdp, IPS, IPA, Bahasa Indonesia. Pada tahap pemilihan desain dilakukan Modul ini memiliki desain dengan ilustrasi dan gambar asli yang membuat siswa lebih mudah memahami konsep yang disajikan pada modul. huruf yang digunakan lebih berwarna diharapkan dapat membuat siswa tertarik dan bahasa yang yang digunakan singkat dan jelas sehingga mudah untuk di pahami oleh siswa, kertas yang digunakan adalah A4 dan sampul menggunakan kertas art paper dengan ketebalan 210 GSM. Tahap selanjutnya adalah perancangan awal di mana pada tahap ini maksudkan untuk merancang modul mulai dari cover, kata pengantar daftar isi serta isi konten modul pada pembelajaran 1 .

3. Tahap Pengembangan (develop)

Tahap pengembangan merupakan tahap pengembangan modul. Berdasarkan hasil desain awal modul kemudian dilakukkan validasi untuk mengetahui tingkat kelayakannya. Adapun validator dalam pengembangan ini yaitu, ahli desain, ahli materi, dan ahli bahasa. Berdasarkan pemberian skor, saran, dan masukan dari ketiga validator maka dilakukan perbaikan pada modul. Setelah modul diperbaiki maka selanjutnya dilakukan uji coba kecil dan kemudian uji coba lapangan akan tetapi, adanya pandemi Covid 19 menjadikan hal tersebut tidak bisa dilakukan jadi hanya berhenti pada pelaksanaan validasi.

4. Tahap Penyebaran (disseminate) 
Arik. Validitas Modul Berbasis Kearifan...

Pada tahap ini dilakukan penyebaran produk yang dihasilkan. Berdasarkan kondisi yang terjadi saat pelaksanaan penelitian maka tahap penyebaran tidak bisa dilakukan.

Instrumen penelitian yang digunakan adalah lembar validasi. Data hasil validasi dianalisis secara deskriptif kuantitatif dan menggunakan rumus berikut.

$$
\text { Persentase }=\frac{\text { Jumlah skor hasil validasi }}{\text { jumlah maksimal skor }} \quad \text { X100\% }
$$

Tabel 1. Kriteria Rata-rata

\begin{tabular}{|c|c|}
\hline Skor & Kriteria \\
\hline $1,00-1,75$ & Sangat Kurang Menarik \\
\hline $1,76<i \leq 2,50$ & Cukup Menarik \\
\hline $2,51<i \leq 3,25$ & Menarik \\
\hline $3,26<i \leq 4,00$ & Sangat Menarik \\
\hline
\end{tabular}

$$
\bar{X}=\frac{\sum_{n=1}^{\infty} x n}{n}
$$

Menurut Arikunto (dalam Yunian Wahyu dan Rully. 2016). Berdasarkan analisis, maka validitas kelayakan modul menggunakan kriteria yang disajikan pada tabel 2 berikut.

Tabel 2. Kriteria Persentase

\begin{tabular}{|c|c|}
\hline Tingkat Pencapaian & Kualifikasi \\
\hline $81 \%-100 \%$ & Sangat layak \\
\hline $61 \%-80 \%$ & Layak \\
\hline $41 \%-60 \%$ & Cukup layak \\
\hline $0 \%-40 \%$ & Tidak layak \\
\hline
\end{tabular}

\section{HASIL}

Berdasarka metode penelitian maka hasil penelitian ini meliputi, hasil tahap pendefinisian, hasil tahap perancangan, dan hasil tahap pengembangan. Adapun ketiganya disajikan pada beberapa tabel dan gambar berikut.

Tabel 3. Perolehan Skor Ahli Desain

\begin{tabular}{|c|c|c|c|}
\hline NO. & INDIKATOR PENILAIAN & TAHAP 1 & TAHAP 2 \\
\hline 1. & Variasi penyajian & 4 & 4 \\
\hline 2. & Pendahuluan & 4 & 4 \\
\hline 3. & Daftar isi & 4 & 4 \\
\hline 4. & Daftar pustaka & 4 & 4 \\
\hline 5. & Jenis huruf & 4 & 4 \\
\hline 6. & Jenis ilustri & 2 & 4 \\
\hline 7. & Pewarnaan huruf & 2 & 4 \\
\hline
\end{tabular}


Arik. Validitas Modul Berbasis Kearifan...

\begin{tabular}{|c|c|c|c|}
\hline 8. & Ukuran Huruf & 2 & 4 \\
\hline 9. & Ukuran kertas & 4 & 4 \\
\hline \multicolumn{2}{|c|}{ Jumlah } & 30 & 36 \\
\hline & Rata-rata & 3,3 & 4 \\
\hline Kriteria Skor & Menarik & Sangat Menarik \\
\hline Presentase & $83 \%$ & $100 \%$ \\
\hline Kriteria Skor & Layak & Sangat Layak \\
\hline
\end{tabular}

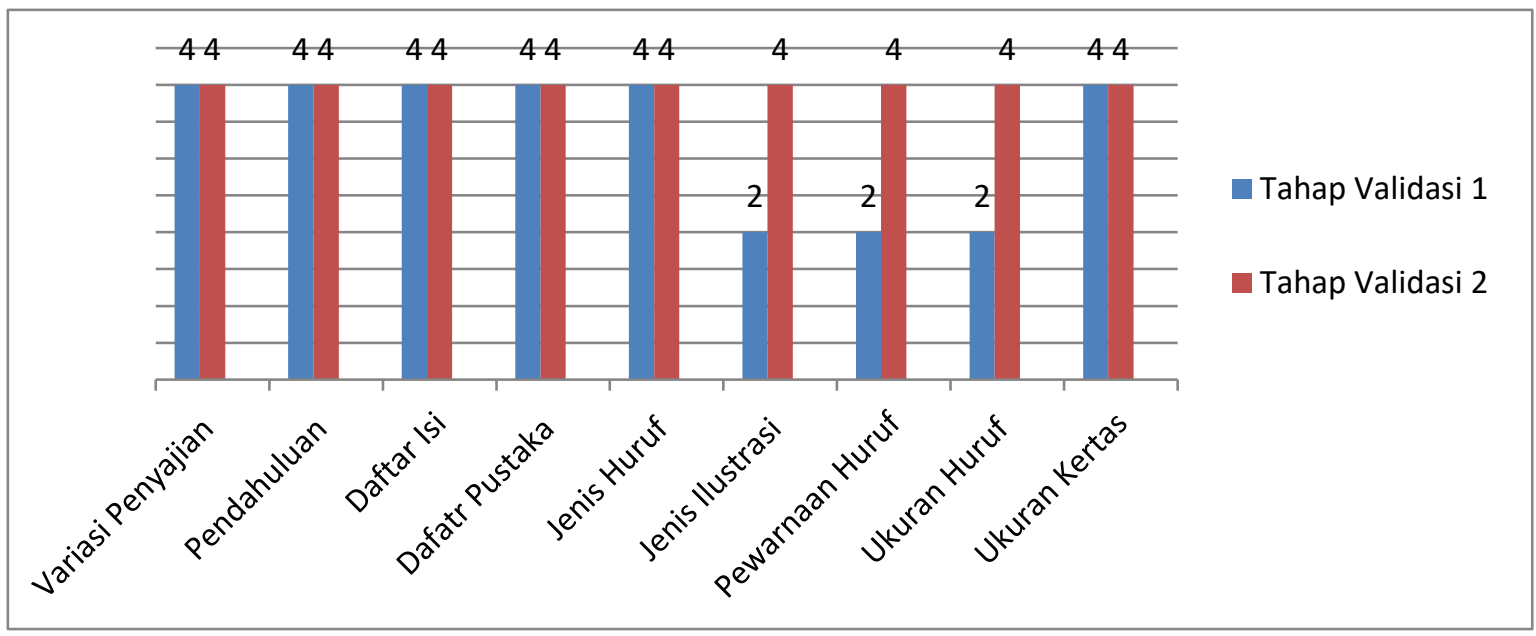

Gambar 2. Perbandingan Skor Validasi Ahli Desain Tahap 1 dan 2

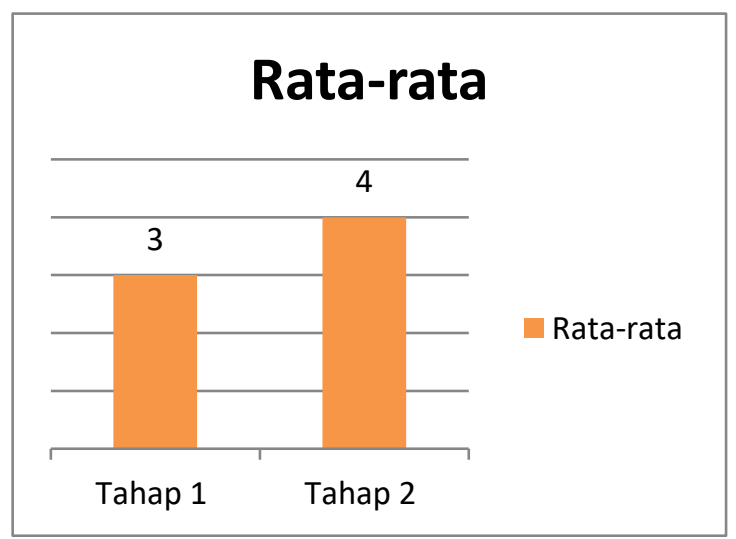

Gambar 2. Rata-rata Penilaian Ahli Desain 
Arik. Validitas Modul Berbasis Kearifan...

\section{Persentase}

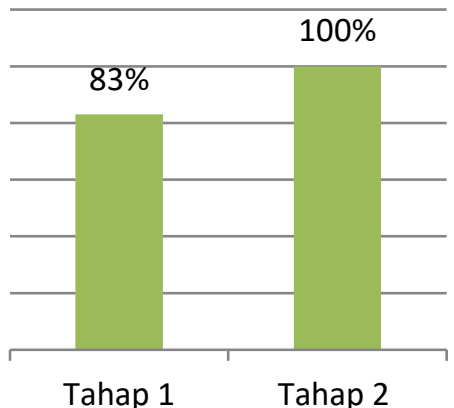

Persentase

\section{Gambar 3. Persentase Penilaian Ahli Desain}

Tabel 4. Perolehan Skor Ahli Materi

\begin{tabular}{|c|c|c|c|}
\hline NO. & INDIKATOR PENILAIAN & TAHAP 1 & TAHAP 2 \\
\hline 1. & Kesesuaian antara Subtema & 3 & 4 \\
\hline 2. & $\begin{array}{l}\text { Keterkaitan KD dengan Materi, tugas, dan } \\
\text { gambar, Serta Video }\end{array}$ & 2 & 4 \\
\hline 3. & Ilustrasi video sesuai dengan materi & 3 & 4 \\
\hline 4. & Berpusat kepada siswa & 3 & 4 \\
\hline 5. & Orientasi kearifan lokal & 3 & 4 \\
\hline & Jumlah & 14 & 20 \\
\hline & Presentase & 3 & 4 \\
\hline & Kriteria Skor & Menarik & Sangat Menarik \\
\hline & Rata-rata & $70 \%$ & $80 \%$ \\
\hline & Kriteria Skor & Layak & Sangat Layak \\
\hline
\end{tabular}

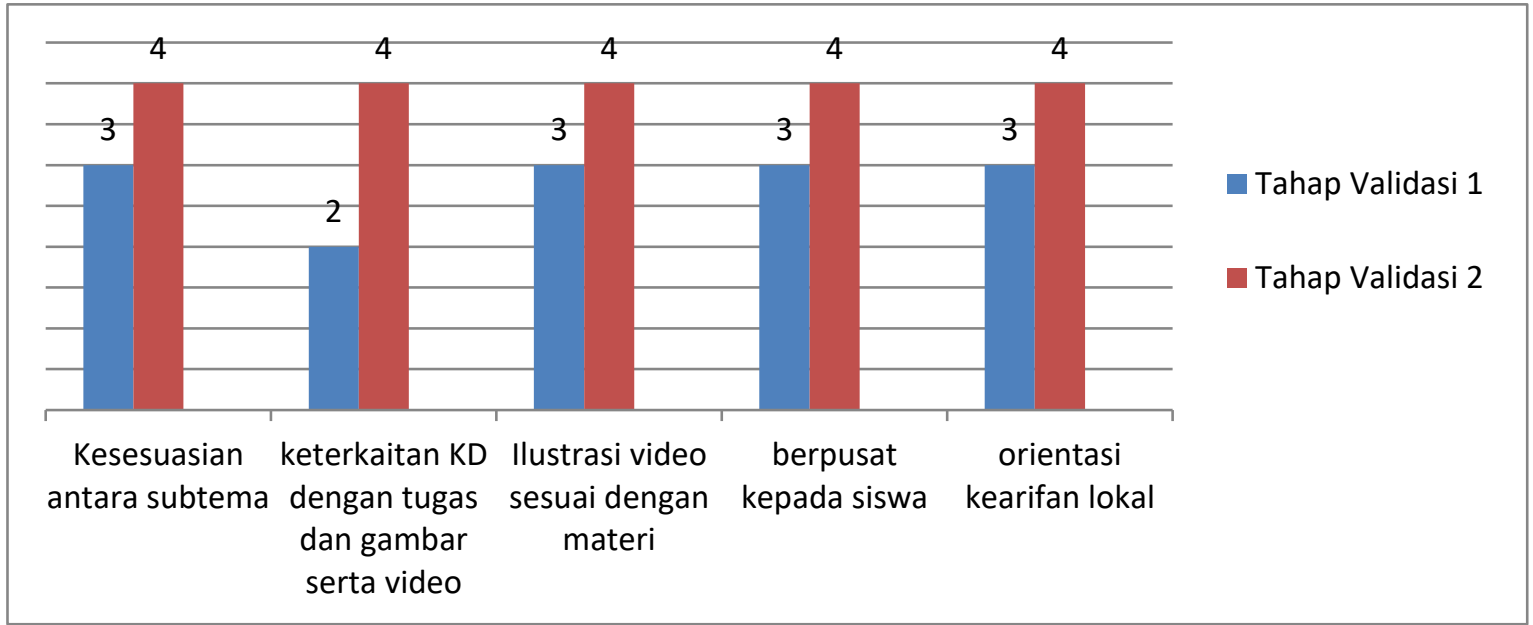

Gambar 4. Perbandingan Skor Validasi Ahli Materi Tahap 1 dan 2 
Arik. Validitas Modul Berbasis Kearifan...

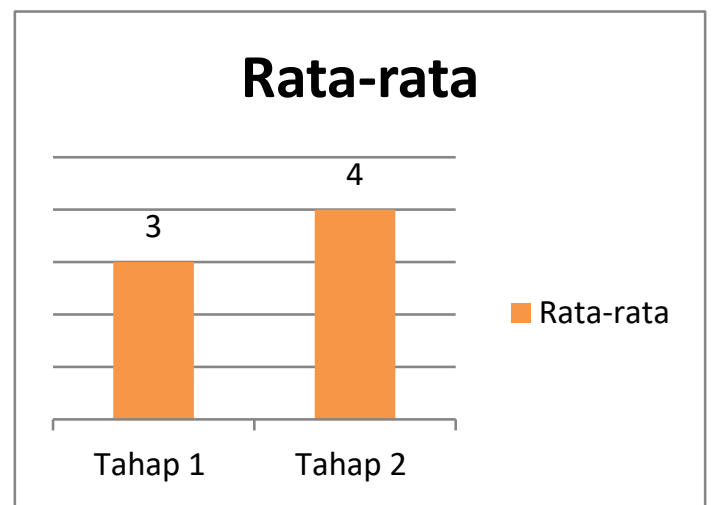

Gambar 5. Rata-rata Penilaian Ahli Materi

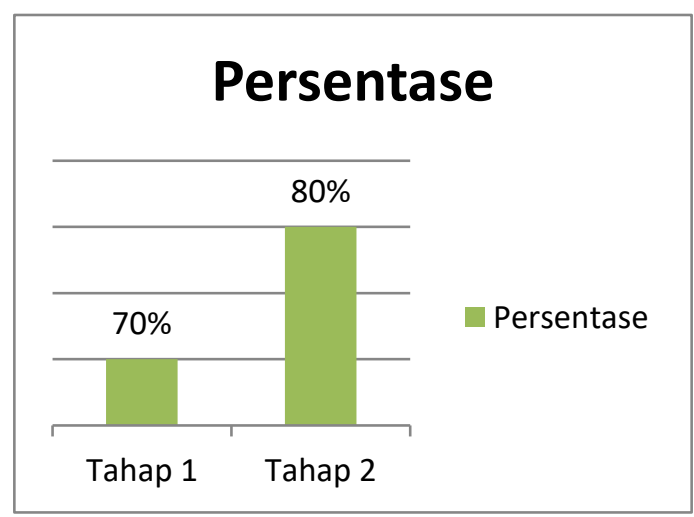

Gambar 6. Persentase Penialaian Ahli Materi

Tabel 5. Perolehan Skor Ahli Bahasa

\begin{tabular}{|c|c|c|c|}
\hline NO. & INDIKATOR PENILAIAN & TAHAP 1 & TAHAP 2 \\
\hline 1. & Susunan Kalimat & 3 & 4 \\
\hline 2. & Penggunaan Bahasa & 3 & 4 \\
\hline 3. & Memperhatikan Emosional & 3 & 4 \\
\hline 4. & Penggunaan Ejaan & 2 & 16 \\
\hline & Jumlah & 11 & 4 \\
\hline & Presentase & 3 & Sangat Menarik \\
\hline & Kriteria Skor & $68,75 \%$ & $100 \%$ \\
\hline & Rata-rata & Layak & Sangat Layak \\
\hline
\end{tabular}


Arik. Validitas Modul Berbasis Kearifan...

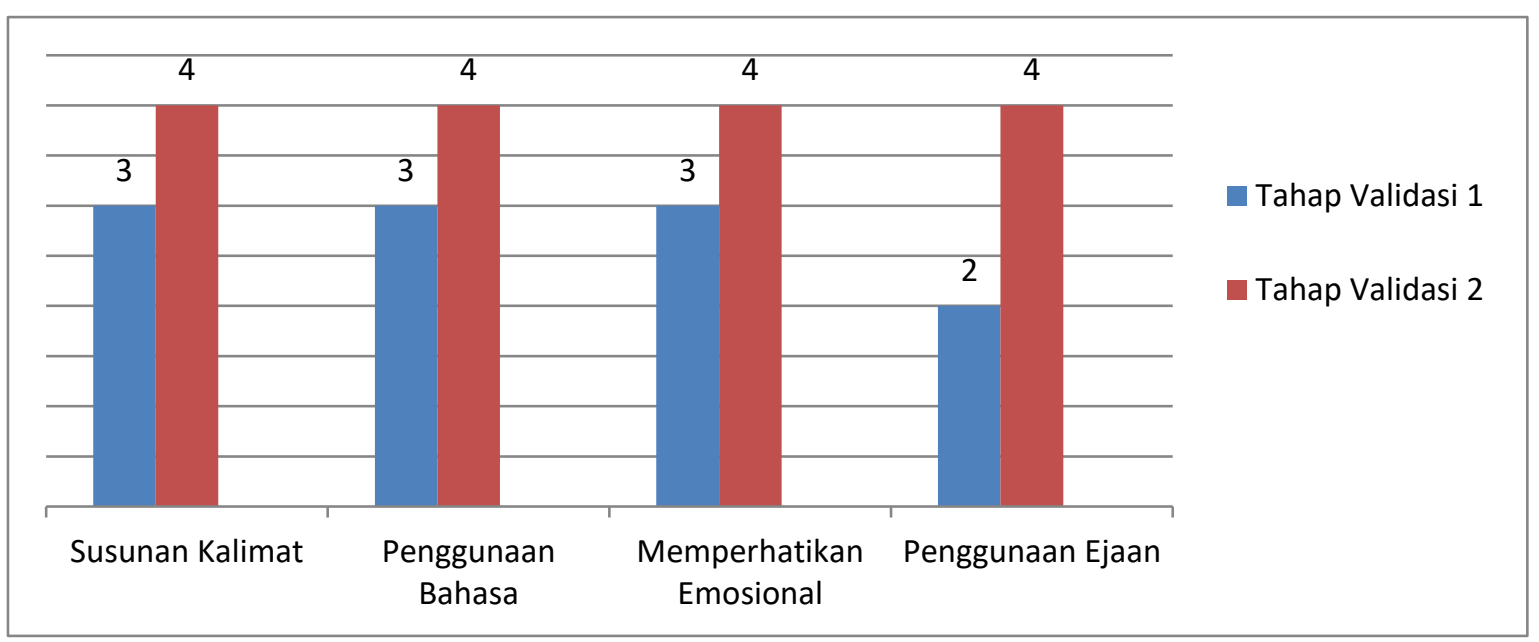

Gambar 7. Perbandingan Skor Validasi Ahli Bahasa Tahap 1 dan 2

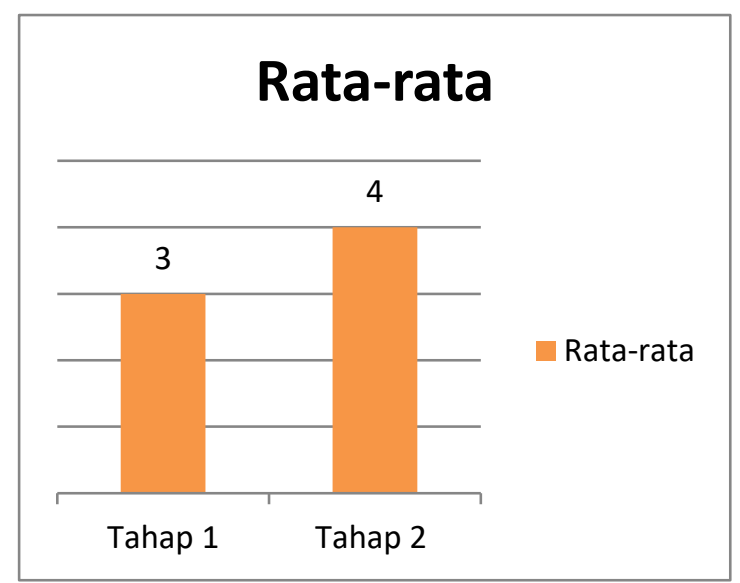

Gambar 8. Rata-rata Validasi Ahli Bahasa

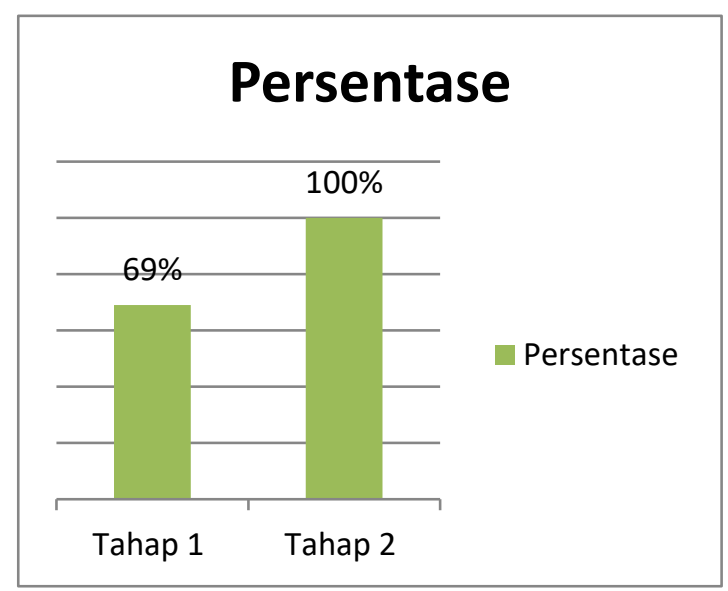

Gambar 9. Persentase Penialaian Ahli materi 
Arik. Validitas Modul Berbasis Kearifan...

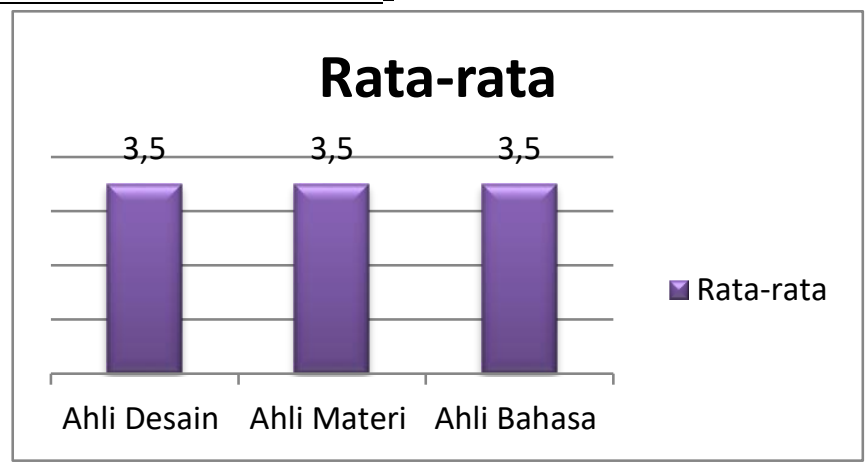

Gambar 10. Rekapitulasi Rata-rata

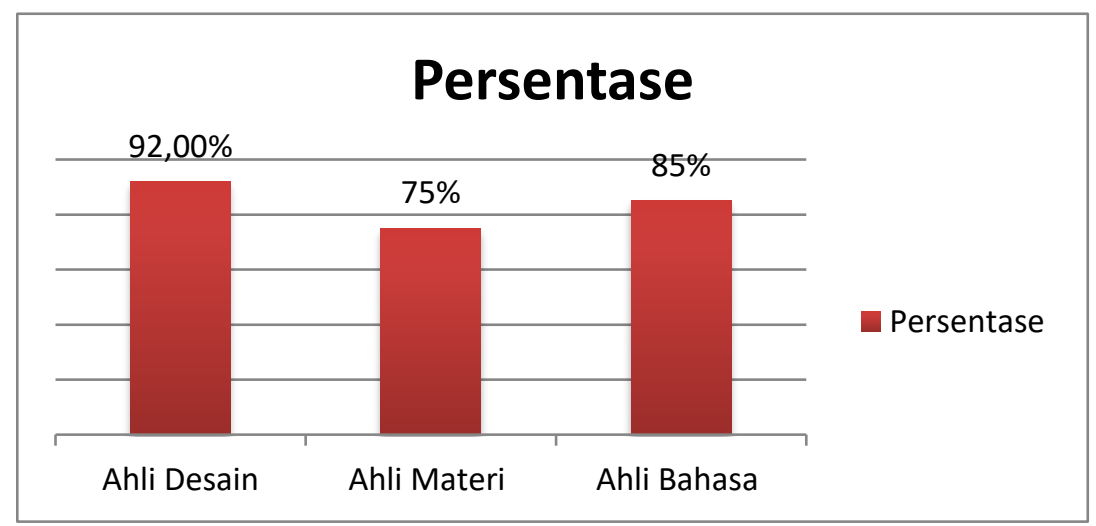

\section{Gambar 11. Rekapitulasi Persentase}

\section{PEMBAHASAN}

Validitas merupakah hal penting dalam sebuah pengembangan produk karena, hasil validitas akan menunjukkan tingkat kelayakan dari produk yang dikembangkan (Oktaviana, 2017) selain itu penilaian dari ahli atau pakar sangat diperlukan untuk mengetahui tingkat kelayakan dari Modul yang dikembangkan (Anwar, 2017). Pada hasil validasi ahli desain yang disajikan pada tabel 3 dan gambar 2 terdapat sembilan indikator penilaian yaitu, varisi penyajian, pendahuluan, daftar isi, daftar pustaka, jenis huruf, jenis ilustrasi, pewarnaan huruf, ukuran huruf, dan ukuran kertas. Pada validasi tahap 1, varisi penyajian, pendahuluan, daftar isi, daftar pustaka, jenis huruf, dan ukuran kertas mendapat skor 4 sedangkan jenis ilustrasi, pewarnaan huruf, ukuran huruf, dan ukuran kertas mendapatkan skor 2. Perbedaan sangat terlihat pada validasi tahap 2 di mana berdasarkan taber 3 dan gambar 2 semua indikator penilaian mendapatkan skor 4. Adapun rata-rata dan persentase hasil validasi dari ahli desain disajikan pada gambar 3 dan 4 . Pada gambar tertera bahwa, ada peningkatan rata-rata 
Arik. Validitas Modul Berbasis Kearifan...

dan persentase yaitu, rata-rata tahap 1 sebesar 3 dan tahap 2 sebesar 4 sedangkan persentase tahap 1 sebesar $83 \%$ tahap 2 sebesar $100 \%$ adanya peningkatan tersebut karena revisi yang dilakukan pada modul berdasarkan masukan dan saran validator pada tahap 1.

Validasi yang dilakukan selain penilaian ahli desain adalah ahli materi. Hasil pada tabel 4 dan gambar 5 menunjukkan ada lima indikator penilaian yaitu, kesesuaian antara subtema, keterkaiatan KD dengan (tugas, gambar, dan video) ilustrasi video sesuai dengan materi, berpusat kepada siswa, dan orientasi kearifan lokal. Tahap 1 pada indikator kesesuaian antara subtema, ilustrasi video sesuai dengan materi, berpusat kepada siswa, dan orientasi kearifan lokal mendapat skor 3 sedangkan keterkaiatan KD dengan (tugas, gambar, dan video) ilustrasi video sesuai dengan materi mendapat skor 2. Berdasarkan hasil skor tahap 1, saran serta masukan validator maka ada perbaikan pada modul dan hal tersebut berdampak pada skor yang didapatkan pada validasi tahap 2. Pada tahap 2 perolehan skor yang didapatkan berdasarkan tabel 4 dan gambar 5 sebesar 4. Adanya skor tersebut berlaku untuk semua indikator, kesesuaian antara subtema, keterkaiatan KD dengan (tugas, gambar, dan video) ilustrasi video sesuai dengan materi, berpusat kepada siswa, dan orientasi kearifan lokal. Rata-rata yang didapatkan dari hasil validasi ahli materi sama dengan ahli desain yaitu, pada tahap satu mendapatkan rata-rata 2 dan tahap 2 mendapatkan 4 sedangkan persentase yang didapatkan pada tahap 1 sebesar $70 \%$ dan tahap 2 mengalami peningkatan sebesar $10 \%$ yaitu menjadi $80 \%$.

Tabel 5 dan gambar 8 merupakan hasil skor validasi pada tahap 1 dan 2 yang didapatkan dari ahli bahasa. Dari data tersebut terdapat empat indikator penilaian yaitu, susunan kalimat, penggunaan bahasa, memperhatika emosional, dan penggunaan ejaan. Pada tahap 1 untuk susunan kalimat, penggunaan bahasa, memperhatika emosional mendapatkan skor 3 sedangkan penggunaan ejaan mendapat skor 2. Berbeda dengan tahap 1 pada tahap 2 mengalami peningkatan skor di mana susunan kalimat, penggunaan bahasa, memperhatikan emosional, penggunaan ejaan mendapat skor 4. Dengan demikian rata-rata sebagaimana ditunjukkan gambar 9 mendapat skor 3 untuk tahap 1 dan skor 4 untuk tahap 2, sedangkan persentase pada tahap 1 sebesar 69\% dan tahap 2 100\%. 
Arik. Validitas Modul Berbasis Kearifan...

Validasi yang dilakukan mendapatkan rekapitulasi hasil rata-rata dan persentase di mana pada gambar 10 untuk ahli desain, ahli materi, dan ahli bahasa mendapatkan 3,5 sedangkan rekapitulasi persentase ahli desain sebesar 92\%, ahli materi $75 \%$, dan ahli bahasa sebesar $85 \%$.

\section{SIMPULAN}

Pada tujuan penelitian ini adalah mengetahui validitas dari modul yang dikembangkan di mana dilihat dari tingkat kelayakan modul tersebut. Kelayakan modul memiliki tiga komponen, desain, materi dan bahasa, sehingga validasi dilakukan kepada tiga ahli tersebut. Berdasarkah hasil penelitian dapat diketahui bahwa pada tiga komponen, desain pada modul memiliki kriteria sangat layak yaitu sebesar 92\%, dari komponen materi pada modul memiliki kriteria layak karena mendapat persentase $75 \%$, dan bahasa yang digunakan pada modul sangat layak digunakan dengan persentase sebesar $85 \%$. Secara keseluruhan validitas modul dilihat dari kelayakan memiliki kriteria sangat layak dengan persentase sebesar $84 \%$.

\section{DAFTAR RUJUKAN}

Alba, Aldine Paramita, Akbar, Sa'dun, Nurchasanah. 2019. Bahan ajar Daerah Tempat Tinggalku Berbasis Kearifan Lokal. Jurnal Pendidikan Teori Penelitian dan Pengembangan, 4:421-421.

http://journal.um.ac.id/index.php/jptpp/article/view/12228/5732.

Alus, Crishterward. 2014. Peran Lembaga Adat Dalam Pelestarian Kearifan Lokal Suku Suhu Di Desa Balisan Kecamatan Suhu Kabupaten Halmahera. Jurnal Acta Diurna Komunikasi, 4: 1-16.

https://ejournal.unsrat.ac.id/index.php/actadiurnakomunikasi/article/view/5995/5 514.

Anwar, Moh Farid Nurul, Ruminiati, Suharjo. 2017. Pengembanagn Modul Pembelajaran Tematik Terpadu Berbais Kearifan Lokal Kabupaten Sumenep Kelas IV Sub Tema Lingkungan tempat Tinggalku. Jurnal Pendidikan Teori Penelitian dan Pengembangan, 10: 1291-1297.

http://journal.um.ac.id/index.php/jptpp/article/view/10059/4793. 
Arik. Validitas Modul Berbasis Kearifan...

Chusna, Ludvi Novisatul, Ekowati, Dyah Worowirastri, dan Kuncahyo. 2019. Modul Pendamping Pembelajaran Tematik Berbasis Kearifan Lokal Blitar Di Kelas IV SD Indonesian Journal of Primary Education (IJPE), 3: 81-92. https://ejournal.upi.edu/index.php/IJPE/article/view/16880/9795.

Daryanto. 2013. Menyususn Modul Bahan Ajar Untuk Persiapan Guru Dalam Mengajar. Yogjakarta: Gava Media.

Deviana, Tyas. 2018. Analisis Kebutuhan Pengembangan Modul Pembelajaran Berbasis Kearifan Lokal Kabupaten Tulungagung Untuk Kelas V SD Tema Bangga Sebagai Bangsa Indonesia. Jurnal Pemikiran dan Pengembangan SD, 6: 47-56. https://ejournal.umm.ac.id/index.php/jp2sd/article/view/5902/5443.

Fajarini, Ulfah. 2014. Peranan Kearifan Lokal Dalam Pendidikan Karakter. Sosio Didaktika Social Science Education Journal, 1: 124-130. http://journal.uinjkt.ac.id/index.php/SOSIO-FITK/article/view/1225/1093.

Irfan, Ahmad dan Winarti, Puput R. 2014. Pengembangan modul Pembelajaran Pada Mata Kuliah Medan Elektromagnetik 1 di Jurusan Teknik Elektro Universitas Negeri Surabaya. Jurnal Pendidikan teknik Elektro, 3: 543-551. https://jurnalmahasiswa.unesa.ac.id/index.php/jurnal-pendidikan-teknik elektro/article/view/9505.

Laksana,Dek Ngurah Laba, Kurniawan, Putu Agus Wawan, Niftalia, Irama. 2016. Pengembangan Bahan Ajar Tematik SD Kelas IV Berbasis Kearifan Lokal Masyarakat Ngada. Jurnal Ilmiah Pendidikan Citra Bakti, 3: 1-10. http://www.ejournal.citrabakti.ac.id/index.php/jipcb/article/view/74/0.

Lamahala, Muhaimin H, Lamen, Sumarni, Uslan. 2018. Pengembangan Media Epidermis Tanaman Jagung (Zea mays L.) Yang Tumbuh Di Kota Kupang Sebagai Sumber Belajar Tambahan Pembelajaran IPA SD Berbasis Kearifan Lokal. Jurnal Ilmiah Pendidikan Citra Bakti, 5: 15-25. https://jurnalilmiahcitrabakti.ac.id/jil/index.php/jil/article/view/5/3.

Munadi. 2010. Media Pembelajaran. Jakarta: Gaung Persada Press 
Arik. Validitas Modul Berbasis Kearifan...

Musanna, Al. 2012. Artikulasi Pendidikan Guru Berbasis Kearifan Lokal untuk Mempersiapkan Guru Yang Memiliki Kompetensi Budaya. Jurnal Pendidikan dan Kebudayaan 18: 328-341. https://jurnaldikbud.kemdikbud.go.id/index.php/jpnk/article/view/92/89.

Oktaviana, Dewinta, Hartini, Sri, dan Misbah. 2017. Pengembangan Modul Fisika Berintegrasi Kearifan Lokal Membuat Minyak Lala Untuk Melatih Karakter Sanggam. Berkala IlmIah Pendidikan Fisika, 5: 272-285. https://ppjp.ulm.ac.id/journal/index.php/bipf/article/view/3894/pdf.

Rozhana, Kardiana Metha dan anwar, Moh. Farid Nurul. 2014. Pengembangan Modul Berbasis Trenggalek Untuk Menumbuhkan Sikap Peduli Lingkungan. Jurnal Bidang Pendidikan 3asar, 39-46. http://ejournal.unikama.ac.id/index.php/JBPD/article/view/3295.

Rukiyati, Purwastuti, Andriani. 2016. Model Pendidikan Karakter Berbasis Kearifan Pada sekolah Dasar Di Bantul Yogyakarta. Jurnal Pendidikan Karakter, 1: 130142. https://journal.uny.ac.id/index.php/jpka/article/view/10743.

Saputra, Aji, Wahyuni, Sri, Handayani, Rif'ati Dina. 2016. Pengembangan Modul IPA Berbasis Kearifan Lokal Daerah Pesisir Puger Pada Pokok Bahasan Sistem Transportasi Di SMP. Jurnal Pembelajaran Fisika, 5:182-189. https://jurnal.unej.ac.id/index.php/JPF/article/view/3967/3095.

Sugiyono. 2015. Metode Penelitian Pendidikan Pendekatan Kuantitatif, Kualitatif dan R\&D. Bandung : Alfabeta Teknik Penyususnan Modul. 2016. (Online). (https://scholar.google.co.id/citations?user=vIk-

StsAAAAJ\&hl=id\#d=gs_md_cita-

$\mathrm{d} \& \mathrm{u}=\% 2 \mathrm{Fcitations} \% 3 \mathrm{Fview}$ _op\%3Dview_citation\%26hl\%3Did\%26user\%3DvI k-StsAAAAJ\%26citation_for_view\%3DvIkStsAAAAJ\%3A2osOgNQ5qMEC\%26tzom\%3D-420 ), Akses 17 Maret 2021

Tinja, Yusintus, Towaf, Siti Malikah, dan Hariyono. 2017. Pengembangan Bahan Ajar Tematik Berbasis Kearifan Lokal Sebagai Upaya Melestarikan Budaya Pada Siswa Sekolah Dasar, 2: 1257-1261. Jurnal Pendidikan Teori, Penelitian, dan Pengembangan. http://journal.um.ac.id/index.php/jptpp/article/view/9990/4723. 
Arik. Validitas Modul Berbasis Kearifan...

Utari, Unga, Degeng, I Nyoman Sudana, dan Akbar, Sa'dun. 2016. Pembelajaran Tematik Berbasis Kearifan Lokal Di Sekolah Dasar Dalam Menghadapi Masyarakat Ekonomi Asean (MEA). Jurnal Dan Teori Praksis Pembelajaran, 1: 39-44. http://journal2.um.ac.id/index.php/jtppips/article/view/226/183.

Wafini, Nafia dan Nurani, Siti. 2018. Model Pembelajaran Tematik Berbasis Kearifan Lokal, Al Bidayah Jurnal Pendidikan Dasar Islam, 10: 256-270. http://jurnal.albidayah.id/index.php/home/article/view/170. 